\title{
A review of the performance of domestic refrigerators
}

\section{Abstract}

8 This paper reviews the published data on the performance and use of domestic refrigerators

9 throughout the world in the last 30 years. While there is considerable legislation defining 10 maximum temperatures during the production, distribution and retailing of chilled food, as 11 soon as the consumer purchases the food, it is outside of any of these legislative 12 requirements. Inadequate domestic refrigeration or cooling is frequently cited as a possible 13 factor in food poisoning incidents. It is clear from the many published surveys that many 14 refrigerators throughout the world are running at higher than recommended temperatures.

15 Since even these recommended temperatures are higher than the 0 to $1^{\circ} \mathrm{C}$ that is usually the 16 recommended temperature range for storing fish and seafood, meat and many chilled 17 products the current situation is even more detrimental to maintaining the high quality life of 18 chilled foods. Despite numerous surveys around the world, how refrigerator temperatures 19 and cleanliness impacts on consumer health remains to be fully assessed.

20 Key words

21 Fridge, consumer handling, temperature control, food safety, domestic hygiene. 
23 Since the late 1980's there has been a considerable increase in legislation throughout the

24 world defining maximum temperatures during the production, distribution and retailing of 25 chilled food. However, as soon as the consumer purchases the food, it is outside of any of 26 these legislative requirements. After a chilled product is removed from a retail display 27 cabinet it is outside a refrigerated environment whilst it is carried around the store and then transported home for further storage. In the home it may be left in ambient conditions or

29 stored in the refrigerator until required. There has been significant concern in recent years

30 over the role of inadequate temperature control and handling in the home on the number of 31 food poisoning incidents (Ryan, Wall, Gilbert, Griffin \& Rowe, 1996).

32 Numerous surveys have been reported from around the world on the domestic storage of 33 refrigerated foods since 1987 (Table 1). These studies, such as those carried out in Sweden 34 (Marklinder, Lindblad, Eriksson, Finnson \& Lindqvist, 2004) and the USA (Redmond \& 35 Griffith, 2003), in general, show remarkable similarities in consumer attitudes and handling 36 of chilled foods and the performance of their fridges. Perhaps even more remarkable is that 37 despite numerous recommendations on handling and storage temperatures, consumer use and 38 the performance of refrigerators remain remarkably unch anged throughout the world over the 39 last 30 years!

\section{2. Temperatures in domestic refrige rators}

41 Spreen (1925) states that in 1919 the mechanical domestic refrigerator passed from the 42 pioneering to the production stage in the USA. Records showed that from 1919 to 1924 there was a $100 \%$ plus increase in sales each year and orders in 1924 were $350 \%$ higher than a year

44 earlier in the USA. The refrigerator is now a common household device and very few 
45 households in the developed world do not own a refrigerator or fridge-freezer for the storage

46 of chilled foods, in the UK penetration is $>99 \%$ (AMA Research, 2003).

47 There have been many developments since a new domestic refrigerator was discussed in 481923 (Anon, 1923). To quote "Experiments conducted by the National Association of Ice

49 Industries over a period of several months have resulted in a domestic refrigerator that is 50 expected to produce better refrigeration in every sense than any of those on the market. It is 51 constructed along lines which make it remarkably efficient and long lasting. Balsa wood is 52 used for the framework and also serves as insulation. Two inches of the wood are used 53 throughout as insulation. The insulation is lined inside and out with five-sixteenths of an inch 54 of artificial stone made from a special waterproof composition with mangasite as a base. The 55 result is a refrigerator which is literally hermetically sealed." There have been considerable 56 developments in the energy efficiency and the refrigeration systems used in domestic 57 refrigerators (Radermacher \& Kim, 1996) however these developments have often been 58 divorced from the temperature within the storage compartment. The temperature at which a

59 refrigerator operates is critical for the safe storage of chilled food. Recommendations in the

60 UK concerning the microbiological safety of foods advise that maximum temperatures in 61 domestic refrigerators should not exceed $5^{\circ} \mathrm{C}$ (Richmond, 1991).

62 Studies on the temperature performance of domestic refrigerators can be divided into those 63 reporting investigations during consumer use and those carried out in the laboratory.

\subsection{Under domestic conditions}

65 A number of surveys of consumer hand ling of refrigerated foods have been carried out over

66 the last 30 years (Table 1) and air temperatures in domestic refrigerators have been measured

67 in a sub-set of these (Table 2). 
68 In the most comprehensive UK study to be carried out so far (Evans, Stanton, Russell \&

69 James, 1991), nearly all the participants when asked what actual temperature their

70 refrigerator operated at were unable to give a value and gave answers based on the method

71 they used to set the temperature dial. A large number of people (32.8\%) set their

72 refrigerators according to the weather, setting the refrigerator to a lower temperature (higher

73 setting) in the summer. It was interesting to note that although 38 participants had a

74 thermometer in their refrigerator only 30 actually used the information to set their refrigerator

75 temperature.

76 There appears to be a difference in awareness of recommended refrigerator temperature

77 settings between countries. In an Australian telephone survey (Jay, Comar \& Goven lock,

78 1999) only $15.5 \%$ of respondents knew the temperature of their fridge. A Swedish survey

79 (Marklinder et al., 2004) found a good level of awareness amongst its survey group, with

$8085 \%$ of respondents knowing the recommended refrigeration temperature (in this case $8^{\circ} \mathrm{C}$ ).

81 However, not all of those consumers put their knowledge into practice, the survey found $40 \%$

82 of food storage temperatures exceeded the maximum recommended temperature for the food

83 being stored. Also only $25 \%$ knew, or regularly measured, the temperature of their

84 refrigerator. A later Irish study found that only $22 \%$ of consumers were aware of the correct

85 temperature to operate their refrigerator (Kennedy, Jackson, Blair, McDowell, Cowan \&

86 Bolton, 2005a) and 23.2\% had a refrigerator thermo meter. Ghebrehewet \& Stevenson (2003)

87 found that after home-based hygiene training the proportion of consumers that were aware of

88 correct operating temperatures rose from 31.7 to $78.4 \%$.

89 Not all studies have actually measured refrigerator temperatures. In some of those that have

90 (Table 2), it is very clear how the temperatures were measured, where the sensors were

91 positioned and for how long the measurements were carried out. In others far less data are

92 provided in the publications so results may not be strictly comparable. To evaluate 
temperatures within refrigerators in the UK Evans et al. (1991) used a miniature data logger

94 with three air and two product sensors was placed into the refrigerator to monitor

95 temperatures every $8 \mathrm{~s}$ and to record mean temperatures every 5 minutes for a period in 96 excess of seven days. Air temperature sensors were positioned in the top, middle and bottom

97 sections of the refrigerator and a simulated food product $(87 \mathrm{~mm}$ diameter by $28 \mathrm{~mm}$ high

98 disc of 'Tylose'; a food substitute; in a petri dish) placed on the middle shelf. Sensors were

99 placed in the geometric centre and centrally on the surface of the Tylose disc.

100 In the Evans study an evaluation of temperatures within each refrigerator showed that the

101 mean temperature over 7 days (evaluated from top, middle and bottom sensors) ranged from

$102-1^{\circ} \mathrm{C}$ to $11^{\circ} \mathrm{C}$. The overall mean air temperature for all the refrigerators in the survey was

$1036^{\circ} \mathrm{C}$, with $70 \%$ of refrigerators operating at average temperatures above $5^{\circ} \mathrm{C}$ (Fig. 1).

104 An investigation carried out in Northern Ireland found similar results with $71 \%$ of 105 refrigerators having a mean internal temperature above $5^{\circ} \mathrm{C}$ (Flynn, Blair \& McDowell, 106 1992). Temperatures were measured by placing $25 \mathrm{ml}$ glass bottles filled with water on the 107 top, bottom and middle shelves. The bottles were left for an unspecified time before the 108 temperature of the water was measured with a T-type thermocouple.

109 A Dutch study (Lezenne Coulander, 1994, cited by Notermans et al., 1997) found 70.4\% of 110 refrigerators above $5^{\circ} \mathrm{C}$, though only $3.2 \%$ at or above $9^{\circ} \mathrm{C}$. However the method of 111 temperature determination is not known. In New Zealand (O’Brien, 1997) placed 112 thermocouples on the top and bottom shelves, closed the door of the refrigerator and waited 113 for 2 minutes before recording the temperatures. Sixty percent of the 50 refrigerators 114 surveyed were outside the 0 to $4^{\circ} \mathrm{C}$ range recommended in New Zealand. Sergelidis, 115 Abrahim, Sarimvei, Panoulis, Karaioannoglou \& Genigeorgi (1997) reported that 25\% of the 116136 domestic refrigerators investigated in Greece had temperatures above $10^{\circ} \mathrm{C}$. However, 117 again the method of temperature measurement was not reported. Worsfold \& Griffith (1997) 
118 used a small data logging system strapped to a perishable product to record the air

119 temperature around the product during transport and during storage in a domestic refrigerator.

120 The position within the refrigerator was not therefore controlled. Recordings were taken at 1

121 minute intervals and products remained in the refrigerator for an average of three days at an 122 overall average temperature of $5.9^{\circ} \mathrm{C}$.

123 In a study of temperatures inside refrigerators, using an unreported measurement method, 124 used by elderly UK consumers (aged 65+) 70\% of a total of 645 fridges surveyed were 125 running above $5^{\circ} \mathrm{C}$ (Johnson, Donkin, Morgan, Lilley, Neale, Page \& Silburn, 1998). Only 126 one was reported to be too cold at $-2^{\circ} \mathrm{C}$ and too warm temperatures correlated with people not 127 living alone and those with low incomes.

128 A USA survey of product temperatures during retail, transport to the home and in the home 129 (Audits International, 1999), using an unspecified method, showed that in only $27 \%$ of the 130939 refrigerators surveyed were product temperatures above $5^{\circ} \mathrm{C}$ after transport home and 131 storage for $24 \mathrm{~h}$. Product temperatures were above $8.3^{\circ} \mathrm{C}$ in $4 \%$ of those refrigerators. The 132 minimum product temperature recorded after $24 \mathrm{~h}$ was $-6^{\circ} \mathrm{C}$ while the highest was $21^{\circ} \mathrm{C}$.

133 Peck, Goodburn, Betts \& Stringer (2006) cite an unreferenced French survey of 2001/2002 as

134 finding that $47 \%$ of yogurt samples in an unspecified number of refrigerators surveyed were 135 at temperatures above $6^{\circ} \mathrm{C}$, and more than $75 \%$ of meat product samples were above $4{ }^{\circ} \mathrm{C}$. 136 Five percent of the refrigerators surveyed were reported to be operating at temperatures 137 above $10^{\circ} \mathrm{C}$.

138 Temperatures at the top, middle and bottom of 119 refrigerators in France were recorded, at a 1392 to 8 minute interval over 7 days, using a data logger by Lauguerre, Derens \& Palagos 140 (2002). In the study a two-dimensional analysis (crossed table) was used in order to verify 141 the relationship between factors (characteristics of refrigerator, use conditions and 
142 characteristics of participants) and between factor and overall temperature. It was found that

143 there was no direct relationship between these, particularly in terms of temperature settings

144 and refrigerator temperatures. Seven percent of refrigerators with high temperature settings

145 still had a low temperature $\left(<2.5^{\circ} \mathrm{C}\right)$ while $6 \%$ of refrigerator that had low temperature

146 settings, still had a high temperature $\left(>10^{\circ} \mathrm{C}\right)$. Analysis of the refrigerators located near heat

147 sources did not enable conclusions to be drawn concerning this effect on temperature since

148 the overall temperature varied from low to high. However, no built-in refrigerators had

149 temperatures under $2.5^{\circ} \mathrm{C}$. The investigation showed that statistically there was no

150 relationship between temperatures measured using a thermometer at a given moment or using

151 a data logger over a 7-day period. An increasing number of refrigerators are sold with a

152 single point temperature display however these authors stated that 'the temperature measured

153 using a thermometer does not represent the true operating conditions of the refrigerator'.

154 Ghebrehewet \& Stevenson (2003) found that after home-based hygiene training and the 155 distribution of refrigeration thermometers the proportion of refrigerators operating above $5^{\circ} \mathrm{C}$ 156 fell from 37 to $15.8 \%$. However the method of measuring the temperature, positions and 157 time span is not mentioned. At that time a review of all European studies showed that overall 158 the average air temperature in European fridges would appear to be $6.64^{\circ} \mathrm{C}$ (Nauta, Litman, 159 Barker \& Carlin, 2003).

160 Since that review, further surveys have been carried out around the world, again with similar 161 results. A 2004 survey of New Zealand Food Safety Authority survey (Anon, 2007), carried 162 out by the Institute of Environmental Science and Research (ERS), found a third of the 53 163 refrigerators surveyed operating above the recommended temperature range of between $1^{\circ} \mathrm{C}$ 164 and $5^{\circ} \mathrm{C}$. A detailed survey of food temperatures of products stored in Swedish consumers 165 fridge's found that $22 \%$ of minced meat samples were stored above $8^{\circ} \mathrm{C}$ and $44 \%$ of ham 166 samples (Marklinder et al., 2004). Refrigerator temperatures from -7.9 to $20.7^{\circ} \mathrm{C}$ were 
167 measure in Ireland by Kennedy et al. (2005a, b) using a data logger placed on the middle

168 shelf and recording every 10 minutes for 72 hours. While in Portugal (Azevedo, Regalo,

169 Mena, Almeida, Carneiro, Teixeira et al., 2005) temperatures, measured at one point using a

170 digital thermometer, were found to be greater than $12.1^{\circ} \mathrm{C}$ in two refrigerators and between

$171 \quad 10.1$ and $12.0^{\circ} \mathrm{C}$ in ten others of the 86 surveyed. In another study, Terpstra, Steenbekkers,

172 de Maetelaere \& Nijhuis (2005) used a glass thermometer kept for 24 hours inside a plastic

173 bottle of water that was placed in the bottle rack in the door of refrigerators. The

174 temperatures measured ranged from 3.8 to $11.5^{\circ} \mathrm{C}$. They found that high refrigerator

175 temperatures were prevalent in households without older ( $>60$ year old) people.

176 In the latest UK study Breen, Brock, Crawford, Docherty, Drummond, Gill et al. (2006) used

177 a liquid in glass thermometer housed in a $23 \mathrm{~mm}$ diameter cylinder of food gel, which was

178 claimed to mimic the thermal behaviour of a food. It appears that only one temperature, at an

179 unstated position in the refrigerator and time, was taken. They recorded temperatures from 1

180 to $12^{\circ} \mathrm{C}$ with a mode of $5^{\circ} \mathrm{C}$ and $33 \%$ above $5^{\circ} \mathrm{C}$.

181 In analysing the data from most of the various surveys reported over the last 30 years Peck et

182 al. (2006) concluded that $61.2 \%$ of refrigerators throughout the world run at temperatures 183 above $5^{\circ} \mathrm{C}$.

184 An analysis of percentage time spent between certain temperatures carried out in the Evans 185 UK study (Evans et al., 1991), showed that the greatest proportion of time (80.3\%) was spent 186 between 3 and $8.9^{\circ} \mathrm{C}$. Only small amounts of time were spent above $9^{\circ} \mathrm{C}$. However, only 4 187 refrigerators $(1.6 \%)$ in the whole survey operated below $5^{\circ} \mathrm{C}$ during all the monitoring period 188 and $33.3 \%$ of refrigerators spent all their time above $5^{\circ} \mathrm{C}$. A further analysis showed that in $18969.9 \%$ of refrigerators the warmest place was in the top and in $45.1 \%$ the coolest place was in 190 the middle (Table 3). However, the top of the refrigerator was not always the warmest and 191 the bottom the coldest place (Table 4). Bakalis, Giannakourou, \& Taoukis (2003) found the 
192 warmest place in the door with the lowest temperature being in the middle position of some

193 refrigerators and the upper tray in other. While Laguerre \& Flick (2004) found the highest

194 temperature could sometimes be in the top and at other times in the middle of the same

195 refrigerator. A New Zealand survey found that in almost three-quarters of the 53

196 refrigerators surveyed higher temperatures were on the top shelf rather than on the bottom

197 shelf (Anon, 2007). A Swedish survey reported that those consumers that made an effort to

198 store food in the coldest location usually believed that location to be the top shelf (Marklinder

199 et al., 2004).

200 In the Evans et al. (1991) study mean temperature range within a refrigerator was found to

201 vary between refrigerator types. There are three main types of refrigerator design. The older

202 style ice-box refrigerators have a box-plate evaporator within the refrigerator (which is often

203 used to store frozen food for a short time). Larder refrigerators have a back-plate evaporator,

204 as do fridge-freezers (which can either have one compressor supplying both fridge and

205 freezer, or two separate compressors). In Evans et al.'s (1991) study, ice-box refrigerators

206 were found to have the smallest temperature range (average $1.8^{\circ} \mathrm{C}$ ); whereas the range in

207 temperature in fridge-freezers and larder refrigerators was nearly twice as great (average of

$2083.4^{\circ} \mathrm{C}$ in fridge-freezers and $3.7^{\circ} \mathrm{C}$ in larder refrigerators) (Table 5). A survey carried out in

209 China found higher ranges in temperature within domestic refrigerators with only $2.3 \%$ of the

210 refrigerators surveyed operating with a temperature range of less than $6^{\circ} \mathrm{C}: 34.1 \%$ had

211 differences of $8-12^{\circ} \mathrm{C}, 34.1 \%$ in the range $12-14^{\circ} \mathrm{C}$ and $29.5 \%$ differences greater than $14^{\circ} \mathrm{C}$

212 (Shixiong \& Jing, 1990).

\section{$213 \quad 2.2$ Under controlled conditions}

214 Little data seems to have been published on the temperature performance of domestic

215 refrigerators under controlled conditions. Data can be found on energy consumption 
216 (Dlugoszewski \& Minczewski, 1984), evaporator coil design (Karpinski, 1984), and the shelf

217 life advantages to be gained with product stored in a special refrigerator containing a $0^{\circ} \mathrm{C}$

218 chamber with fan air circulation (Olsson, 1988). Current standards for domestic refrigerators

219 contain some temperature tests that are carried out under controlled conditions on empty,

220 closed refrigerators. In domestic use refrigerator doors are opened, refrigerators are not

221 usually empty but range from near empty to crammed full and often food at ambient

222 temperature, or above, is placed in them.

223 Some data has been published from experiments carried out on examples of three types of

224 refrigerator (James \& Evans, 1992b). These were a 6 cubic foot dual compressor fridge-

225 freezer (No.1), a 6 cubic foot single compressor fridge-freezer (No.2), and a 4 cubic foot free

226 standing domestic refrigerator with an ice-box compartment (No.3).

227 When tested empty and set to the manufacturers recommended setting, temperatures in the 228 ice box refrigerator (No.3) were uniform and low with a minimum of $-1.4^{\circ} \mathrm{C}$ on the bottom 229 shelf and a maximum of $5.9^{\circ} \mathrm{C}$ in the door. Average temperatures were between 230 approximately 0.5 and $1.5^{\circ} \mathrm{C}$ on the shelves and just above $3^{\circ} \mathrm{C}$ in the door with a cycle of 231 less than $0.5^{\circ} \mathrm{C}$. There was a much larger temperature range in the two fridge-freezers 1.7 to

23214.3 in No.1 and -6.7 to 10.7 in No.2. Average temperatures were far less uniform in the 233 chilled food compartment of the fridge-freezers. In fridge-freezer No.1 the average 234 temperature of the top shelf was up to $5^{\circ} \mathrm{C}$ higher than that measured on the middle shelf 235 which was the coolest area in the appliance. Highest average temperatures of approximately 2367.5 and $10^{\circ} \mathrm{C}$ were measured on the top shelves of the fridge-freezers. In fridge-freezer No.2 237 the average temperature on the bottom shelf reached $-2^{\circ} \mathrm{C}$ at the minimum point in the 238 temperature cycle.

239 Loading 12 packs (dimensions $100 \times 150 \times 25 \mathrm{~mm}$ ) of "Tylose" (the Karlsruhe Test 240 Substance, a simulated food) that had been pre-cooled to $5^{\circ} \mathrm{C}$ into the ice box refrigerator 
241 reduced the mean temperatures by between 1.2 and $2.0^{\circ} \mathrm{C}$. The temperature change caused

242 by loading was similar in magnitude in fridge-freezer No.2 where the mean temperature of 243 the top shelf rose by $0.7^{\circ} \mathrm{C}$ and the mean at other positions dropped by between 0.5 and $2441.1^{\circ} \mathrm{C}$. It was also noted that the length of the refrigeration cycle increased from 245 approximately $0.75 \mathrm{~h}$ to $1 \mathrm{~h}$. In fridge-freezer No.1 the magnitude of the temperature cycle 246 was substantially reduced. The magnitude and position of the maximum temperature was 247 also influenced by loading from a value of $14.3^{\circ} \mathrm{C}$ and located on the top shelf to a reduced 248 value of $9.8^{\circ} \mathrm{C}$ and a location on the bottom shelf.

249 Food is often loaded warm into refrigerators after purchase from retail stores. Loading a 250 small amount of warm $\left(20^{\circ} \mathrm{C}\right)$ food, 2 joints (approximately 17.5 by 7.6 by $3.6 \mathrm{~cm}, 195 \pm 10 \mathrm{~g}$ ) 251 and 2 drumsticks (approximately 12 by 6 by $3 \mathrm{~cm}, 120 \pm 10 \mathrm{~g}$ ) of simulated chicken (Tylose) 252 showed up the poor cooling performance of domestic refrigerators. Over $2 \mathrm{~h}$ was required in 253 the ice box refrigerator to reduce the surface temperature of the drumsticks and portions to $2547^{\circ} \mathrm{C}$ compared with over $5 \mathrm{~h}$ in the fridge freezer. Drumsticks in the domestic refrigerator 255 always cooled faster than the larger portions. However, in the fridge-freezer portions on the 256 middle shelf cooled faster than drumsticks positioned on the top shelf.

257 Laguerre \& F lick (2004) measured the air temperature at 25 different positions in an empty 258 refrigerator with an evaporator fitted inside the vertical back wall and at three positions on 259 the internal walls. The mean air temperature over $24 \mathrm{~h}$ was $6.3^{\circ} \mathrm{C}$ with a minimum value of 2603.8 and a maximum of $8.3^{\circ} \mathrm{C}$. At any time there was typically a $4^{\circ} \mathrm{C}$ range in temperatures 261 between extreme values and a temperature cycle (approximately $1.5 \mathrm{~h}$ ) of approximately $4^{\circ} \mathrm{C}$ 262 at any measurement point. The mean wall temperatures at the top, middle and bottom were $2639.1,5.4$ and $5.7^{\circ} \mathrm{C}$ respectively. In the refrigerator a $4.8 \mathrm{~cm}$ diameter Saveloy sausage took $2646 \mathrm{~h}$ to cool from 20 to $6^{\circ} \mathrm{C}$. 
265 Sun, Singh \& O'Mahony (2005) investigated the effect on quality of storing steak, minced

266 beef patty and salmon in five refrigerators with different environmental conditions (average

267 temperature and temperature fluctuation). All the refrigerators had a compartment

268 specifically for storing fresh meat products. Average temperatures in the five compartments

269 ranged from -4.8 to $+1.7^{\circ} \mathrm{C}$ and all the standard deviations were less than $1.0^{\circ} \mathrm{C}$. The

270 microbial condition of the steak and mince was acceptable for 8 days and the salmon for

2714 days in all five refrigerators. In the refrigerator operating at $-4.8^{\circ} \mathrm{C}$ all the products were

272 acceptable after 10 days. However, although not mentioned in the paper all the samples must

273 have been partially frozen at this storage temperature. The authors state that panellists

274 preferred samples stored under or near ultra-chilled conditions rather than samples stored

275 under standard refrigerated conditions.

\section{3. Hygienic status}

277 Many cases of food poisoning originate in the domestic environment and can be associated 278 with improper food handling and ineffective hygiene by consumers. Redmond \& Griffith 279 (2003) reviewed some of the many studies that have been carried out. A number of 280 pathogenic bacterial were found in kitchens and specific sites were most highly 281 contaminated. The handle on a refrigerator door is used many times during a day and is not 282 regularly cleaned. It is not therefore surprising that of the five sites they sampled, Hayson \& 283 Sharp (2006) state "the highest mean Enterobacteriaceae count was found on the refrigerator 284 handle $\left(6.1 \times 10^{4} \pm 4.2 \times 10^{3} \mathrm{cfu} \mathrm{m}^{-1}\right)$." Accumulated dirt and grime in recessed areas of door 285 handles was considered to produce a hygiene risk especially for children whose small figures 286 would penetrate further.

287 Some recent surveys have published specific data on the hygienic status of domestic fridges.

288 In France, Dieuleveux, Collobert, Dorey \& Guix (2005) specifically looked for Listeria spp. 
289 in sixty household refrigerators. They only found a strain of Listeria innocua in the

290 vegetable compartment of one. However, an Irish survey of the hygienic status of domestic 291 refrigerators (Kennedy et al., 2005a) found a wide range of undesirable bacteria and 292 pathogens. Fifty two percent of refrigerators contained at least one pathogen. A higher 293 general incidence of pathogens and higher Aerobic Plate Counts (APCs) were found in urban 294 consumers refrigerators than those of rural consumers, and consumers under 25 were more 295 likely to have one or more pathogens present in their refrigerators. Interestingly the 296 refrigerators of consumers from socioeconomic group $\mathrm{ABC} 1$ had significantly higher APCs 297 than those belonging to members of the C2DE group. Further analysis by Kennedy et al. 298 (2005b), found that "conscientious food handlers were statistically less likely to have higher 299 TVCs (Total Viable Counts), "any pathogen”, Staphylococcus aureus or Salmonella enterica 300 in their refrigerator". A follow up study (Smyth, Kennedy, Twohig, Miajlovic, Bolton \& 301 Smyth, 2006) concluded, "that the average Irish household refrigerator harbours potential 302 enterotoxin-producing $S$. aureus that may or may not be of animal origin and, accordingly, is 303 a potential reservoir for staphylococcal food poisoning." Further assessments have shown 304 high APC contamination levels (Jackson, Blair, McDowell, Kennedy \& Bolton, 2007). 305 Values ranged from 2.91 to $8.78 \log _{10} \mathrm{cfu} \mathrm{cm}^{-2}$ with an average of $7.4 \log _{10} \mathrm{cfu} \mathrm{cm}^{-2}$ in the 306342 refrigerators sampled. Almost a quarter of refrigerators yielded coliform contamination 307 levels greater than $3 \log _{10} \mathrm{cfu} \mathrm{cm}^{-2}$ and Escherichia coli was isolated from just over $1 \%$ of 308 refrigerator surfaces. A small Japanese study (Ojima, Toshima, Koya, Ara, Kawai \& Ueda, 309 2002) found high coliform counts in the vegetable storage tray of refrigerators, which they 310 associated with contamination from unwrapped raw fruits and vegetables, and cited as a 311 possible source of cross-contamination of fruits and vegetables that are eaten uncooked.

312 In the USA, Li-Cohen \& Bruhn (2002) reported that their survey of 2000 (33\% response rate) 313 randomly selected households "suggest that women, lower-income households, people 65 
314 years and older, and non-college graduates practice safer food handling methods than men,

315 higher-income households, people younger than 65 years, and college or postcollege 316 graduates."

317 Interestingly (according to one survey) French women's immediate thoughts on home 318 hygiene put food hygiene and conservation low in their considerations (Marrakchi, Stahl, 319 Berthelot, Squinazi, Audurier, Boudene et al., 2002). Spontaneously, the word "hygiene" 320 called to mind cleanness (46\%), house keeping (20\%), but food hygiene or body hygiene was 321 mentioned by only $3 \%$ of women. The three most spontaneously mentioned places at home, 322 as requiring strict hygiene, were the kitchen (83\%), bathroom (78\%), and restroom (67\%).

323 The refrigerator was spontaneously mentioned by only $4 \%$ of surveyed women, but was rated 324 as $9-10$, on the risk scale, by $82 \%$ of the same women. The bad conservation of food was mentioned by only $8 \%$ of women, at the same rank as the presence of pets.

326 It is not therefore surprising that a survey of consumers in Portugal (Azevedo et al., 2005)

327 found that only $6 \%$ of those surveyed cleaned their fridge weekly, while more than $80 \%$ 328 cleaned only monthly or less frequently. Of these only $8 \%$ were cleaning with appropriate 329 proprietary cleaning products. However, the incidence of listeria in these fridges was low, 330 Listeria monocytogenes was only found in 3 out of 86 refrigerators. Zickrick, Wittenberg \& 331 Kiewel (1995) found high bacterial levels, $>100 \mathrm{cfu} \mathrm{cm}^{2}$, on the inner floor areas of $30.6 \%$ of 332 the 59 domestic refrigerators they investigated. They recommended that an adequate 333 cleaning and disinfection system would be advisable for this region and the inner door 334 surface for prophylactic improvement of refrigerator hygiene. Welsh studies (Parry, Slader, 335 Humphrey, Holmes, Guildea \& Palmer, 2005) have shown that household kitchens with dirty 336 refrigerators are no more likely to give rise to an episode of salmonella infection than clean 337 kitchens. The presence of visible dirt was not found to be a risk factor for sporadic 338 salmon ella infection (Parry, Palmer, Slader \& Humphrey, 2002). 
339 Increasingly the use of predictive microbial growth models is revealing potential problems

340 with the temperature levels found in domestic refrigerators. Nauta et al. (2003) predicted

341 probable levels of Bacillus cereus in packages of vegetable puree at the moment the 342 consumer takes the product from their refrigerator. A psychrotrophic strain was predicted to 343 end up above a threshold level of $5 \log _{10} \mathrm{cfu}^{-1}$ in $0.9 \%$ to $6.3 \%$ of the vegetable puree 344 packages. This indicated that even if the puree was stored at $4{ }^{\circ} \mathrm{C}$ in the domestic refrigerator 345 and use-by-date (UBD) was respected, the threshold level may be passed. Notermans, 346 Dufrenne, Teunis, Beumer, Giffel \& Peeters Weem (1997) predicted that 7 to $10 \%$ of milk 347 consumed in the Netherlands contained levels of $B$. cereus that exceeded safety criteria. 348 They concluded that storage conditions were an important factor and that Dutch consumers 349 did not always meet the prescribed storage conditions,

\section{4. Conclusions}

351 Despite all these surveys, how fridge temperatures and cleanliness impacts on consumer 352 health remains to be fully assessed. What is clear is that many refrigerators throughout the 353 world are running at higher than recommended temperatures. Since even these recommended 354 temperatures are higher than the 0 to $1^{\circ} \mathrm{C}$ that is usually the recommended temperature range 355 for storing fish and seafood, meat and many chilled products the current situation is even 356 more detrimental to maintaining the high quality life of chilled foods. At present domestic 357 storage of chilled foods would appear to be the weakest link in the entire chill-chain.

358 A recent risk assessment of chilled foods carried out for the UK Food Standards Agency 359 (Peck et al., 2006) concluded that on average a UK hous ehold replaces its refrigerator/fridge360 freezer every 7.75 years and that while the "improved energy efficiency of UK domestic 361 refrigeration equipment is documented (it) is not clear how the replacement of equipment has 362 affected, if at all, UK domestic refrigerator performance". This suggests that regular 
comprehensive surveys of the performance of domestic refrigerators are required, and that in

364 the particular case of the UK it is high time to reassess current knowledge. However, it is not

365 clear how representative this is of replacement practices in other parts of the world. Data

366 from the USA indicates that the average lifetime of a typical refrigerator there is between 14

367 and 18 years (Kim, Keoleian \& Horie, 2006).

368 There are no technical reasons why the temperature performance of domestic refrigerators are not substantially better than they are at present. In 1992 a group of mechanical engineering students at the University of Bristol were given the task of designing a domestic refrigerator with the improved temperature specification shown in Table 6. Gigiel, Douglas, Fawcett,

372 Lewis \& Watson (1994) reported that the prototype produced more than met the specification 373 (Table 6) and "had the potential as a viable product in the market place".

\section{References}

AMA Research (2003). Kitchen Appliance Report UK 2003. AMA Research Ltd, Cheltenham, Glouc estershire, UK.

Anon (1923). New domestic refrigerator. Refrigerating Engineering, 9(12), 387.

Anon (2007). Foodborne illness in the refrigerator. Food safety news - New Zealand - FoodWorks. URL: http://www. foodworks.co.nz/news/newssafety.htm (last acc essed: 16.01.2007).

Azevedo, I., Regalo, M., Mena, C., Almeida, G., Cameiro, L., Teixeira, P., Hogg, T., \& Gibbs, P.A. (2005).

Bakalis, S., Giannakourou, M.C., \& Taoukis, P. (2003). Effect of domestic storage and cooking conditions on the risk distribution in ready to cook meat products. $9^{\text {th }}$ International Congress on Engineering and Food (ICEF9), Montpellier, 7-11 March, 2003. 

487-494.

Daniels, R.W. (1998). Home food safety. Food Technology, 52(2), 54-56.

Dieuleveux, V., Collobert, J.F., Dorey, F., \& Guix, E. (2005). Surveillance of the contamination by listeria spp of refrigerators. Sciences Des Aliments, 25(2), 147-155.

Dlugoszewski, B. \& Minczewski, R. (1984). Energy savings in small refrigerators. Clodnictwo, 6, 25-27.

Evans, J. (1992). Consumer handling of chilled foods - perceptions and practice. International Journal of Refrigeration, 15(5), 290-298.

Evans, J.A., Stanton, J.I., Russell, S.L., \& James, S.J. (1991). Consumer handling of chilled foods: A survey of time and temperature conditions. MAFF Public ations, London PB 0682.

Flynn, O.M.J., Blair, I., \& McDowell, D. (1992). The efficiency and consumer operation of domestic refrigerators. International Journal of Refrigeration, 15(5), 307-312.

Gigiel, A.J., Douglas, A., Fawcett, R., Lewis, M., \& Watson, M. (1994). Improving the domestic refrigerator. Proceedings of the Institute of Refrigeration, 90, 1993-94, 45-53.

Ghebrehewet, S., \& Stevenson, L. (2003). Effectiveness of home-based food storage training: a community

Haysom, I.W., \& Sharp, A.K. (2005). Bacterial contamination of domestic kitchens over a 24-hour period. British Food Journal, 107(7), 453-466.

Jackson, V. (2003). Food safety knowledge and practices in Irish homes. PhD Thes is in preparation. University of Uls ter at Jordanstone. foodborne pathogens domes tic refrigerators. Food Control, 18, 346-351. Journal of Refrigeration, 15(5), 299-306. 
Jay, L.S., Comar, D., \& Govenlock, L.D. (1999). A national Australian food safety telephone survey. Joumal of Food Protection, 62(8), 921-928.

Johnson, A.E., Donkin, A.J.M., Morgan, K., Lilley, J.M., Neale, R.J., Page, R.M., \& Silburn, R. (1998). Food safety knowledge and practice among elderly people living at home. Journal of Epidemiology and Community Health, 52, 745-748.

Karpinski, W. (1984). Investigations towards the elaboration of a series of evaporators for domestic refrigerators. Clodnictwo, 6, 7-10.

Kennedy, J., Jackson, V., Blair, I.S., McDowell, D.A., Cowan, C., \& Bolton, D.J. (2005a). Food safety knowledge of consumers and the microbiological and temperature status of their refrigerators. Journal of Food Protection, 68(7), 1421-1430.

Kennedy, J., Jackson, V., Cowan, C., Blair, I., McDowell, D., \& Bolton, D. (2005b). Consumer food safety knowledge - segmentation of Irish home food preparers based on food safety knowledge and practice. British Food Journal, 107(7), 441-452.

Kim, H.C., Keoleian, G.A., \& Horie, Y.A. (2006). Optimal household refrigerator replacement policy for life cycle energy, greenhouse gas emissions, and cost. Energy Policy, 34, 2310-2323.

Koutsoumanis, K., \& Taoukis, P.S. (2005). Meat safety, refrigerated storage and transport: modelling and management. In J.N. Sofos (Ed.), Improving the safety of fresh meat (503-561). Woodhead Publishing Ltd, ISBN 1855739550.

Laguerre, O., Derens, E., \& Palagos, B. (2002). Study of domestic refrigerator temperature and analysis of

Laguerre, O., \& Flick, D. (2004). Heat trans fer by natural convection in domestic refrigerators. Journal of Food Engineering, 62, 79-88. Protection. Leeuwarden, The Netherlands. to the plate: A comprehensive consumer survey. Journal of Food Protection, 65(8), 1287-1296. 
Marklinder, I.M., Lindblad, M., Eriksson, L.M., Finnson, A.M., \& Lindqvist, R. (2004). Home storage temperatures and consumer handling of refrigerated foods in Sweden. Journal of Food Protection, 67(11), $2570-2577$.

Marrakchi, C., Stahl, J.P., Berthelot, P., Squinazi, F., Audurier, A., Boudene, C., Bousquet, J., Lejeune, B., Morin, O., Aubry, M.C., Duhuot, D., Fleury, P., \& Cochet, C. (2002). Home hygiene as unders tood by French women. Medecine Et Maladies Infectieuses, 32(1), $41-48$.

Nauta, M.J., Litman, S., Barker, G.C., \& Carlin, F. (2003). A retail and consumer phase model for exposure

Notermans, S., Dufrenne, J., Teunis, P., Beumer, R., Giffel, M., \& Peeters Weem, P. (1997). A risk assessment study of Bacillus cereus present in pasteurized milk. Food Microbiology, 14, 143-151.

O'Brien, G.D. (1997). Domestic refrigerator air temperatures and the public's awareness of refrigerator use. International Journal of Environmental Health Research, 7, 141-148.

Olsson, P. (1988). Comparison of the quality of products stored in home refrigerators with or without forced convection and regular automatic defrosting. Refrigeration for Food and People, Meeting of IIR

Ojima, M., Toshima, Y., Koya, E., Ara, K., Kawai, S., \& Ueda, N. (2002). Bacterial contamination of Japanese households and related concern about sanitation. International Journal of Environmental Health Research,

Parry, S.M., Slader, J., Humphrey, T., Holmes, B., Guildea, Z., \& Palmer, S.R. (2005). A cas e-control study of 459 domestic kitchen microbiology and sporadic salmonella infection. Epidemiology and Infection, 133(5),

Parry, S.M., Palmer, S.R., Slader, J., \& Humphrey, T. (2002). Risk factors for salmonella food poisoning in the

Peck, M.W., Goodburn, K.E., Betts, R.P., \& Stringer, S.C. (2006). Clostridium botulinum in vacuum packed 464 (VP) and modified atmophere packed (MAP) chilled foods. Final Project Report July 2006 (FS A Project B13006), Institu te of Food Research, Norwich, UK. Refrigeration, 19(1), 61-69. 
Redmond, E.C., \& Griffith, C.J. (2003). Consumer food handling in the home: A review of food safety studies. Journal of Food Protection, 66(1), 130-161.

Richmond, M. (1991). The microbiological safety of food part II. Report of the committee on the microbiologic al safety of food. HMSO, London.

Rose, S.A., Steadman, S. \& Brunskill, R. (1990). A temperature survey of domestic refrigerators. CCFRA Technical Memorandum No. 577.

Ryan, M.J., Wall, P.G., Gilbert, R.J., Griffin, M. \& Rowe, B. (1996). Risk factors for outbreaks of infectious intestinal disease linked to domestic catering. Communicable Disease Review CDR Review, 6(13), R179R182.

Sergelid is, D., Abrahim, A., Sarimvei, A., Panoulis, C., Karaioannoglou, Pr. \& Genigeorgi, C. (1997). Temperature distribution and prevalence of Listeria spp. in domestic, retail and industrial refrigerators in Greece. Internation al Journal of Food Microbiology, 34, 171-177.

Shixiong, B., \& Jing, X. (1990). Testing of home refrigerators and measures to improve their performance. Progress in the Science and Technology of Refrigeration in Food Engineering, Meeting of IIR Commission B2, C2, D1, D2/3, Dresden (Germany), 411-415.

Smyth, D.S., Kennedy, J., Twohig, J., Miajlovic, H., Bolton, D., \& Smyth, C.J. (2006). Staphylococcus aureus isolates from Irish domestic refrigerators possess novel enterotoxin and enterotoxin-like genes and are clonal in nature. Journal of Food Protection, 69(3), 508-515.

Spreen, C.C. (1925). Hous ehold refrigeration and research work. Refrigeration Engineering, 11(13), 416417,432.

Sun, S., Singh, R.P., \& O'Mahony, M. (2005). Quality of meat products during refrigerated and ultra-chilled storage. Journal of Food Qua lity, 28(1), 30-45.

Taoukis, P.S., Giannakourou, M.C., Koutsoumanis, K., \& Bakalis, S. (2005) Modelling the effect of house hold chilled storage conditions on the risk distribution in meat products. $3^{\text {rd }}$ International Symposium on: Applications of modelling, as an innovative technology in the Agri-Food Chain, Leuvan, Belgium.

Terpstra, M.J., Steenbekkers, L.P.A., de Maetelaere, N.C.M., \& Nijhuis, S. (2005) Food storage and disposal: consumer practices and knowledge. British Food Journal, 107(7), 526-533. 
495 Van Garde, S.J. \& Woodburne, M.J. (1987). Food discard practices of hous eholds. Journal of the American 496 Dietetic Association, 87, 822-829.

497 Victoria, R. (1993). Ne joves pas avec le froid. 50 millions de consommateur. 267, 36-37.

498 Worsfold, D., \& Griffith, C. (1997). Food safety behaviour in the home. British Food Journal, 93(3), 97-104.

499 Zickrick, V.K., Wittenberg, U., \& Kiewel, S. (1995). Study on the microbial condition of inner surfaces and air 500 of domestic refrigerators. Archiv Fur Leben smittelhygiene, 46(4), 91-94. 
501 Figure legends:

502 Table 1. Published surveys of domestic storage of refrigerated foods carried out in the last 30

503 years in date order

504 Table 2. Air temperatures measured in surveys of domestic refrigerators in homes

505 Table 3. Position of highest temperature within refrigerators investigated (source: Evans et 506 al., 1991)

507 Table 4. Positions of lowest and highest mean temperatures in refrigerators investigated

508 (source: Evans et al., 1991)

509 Table 5. Temperature range in refrigerator types investigated (source: Evans et al., 1991)

510 Table 6. Typical and improved performance specification for a domestic refrigerator

511 Fig. 1. Overall mean temperatures for all refrigerators in survey (source: Evans et al., 1991) 
Click here to download high resolution image

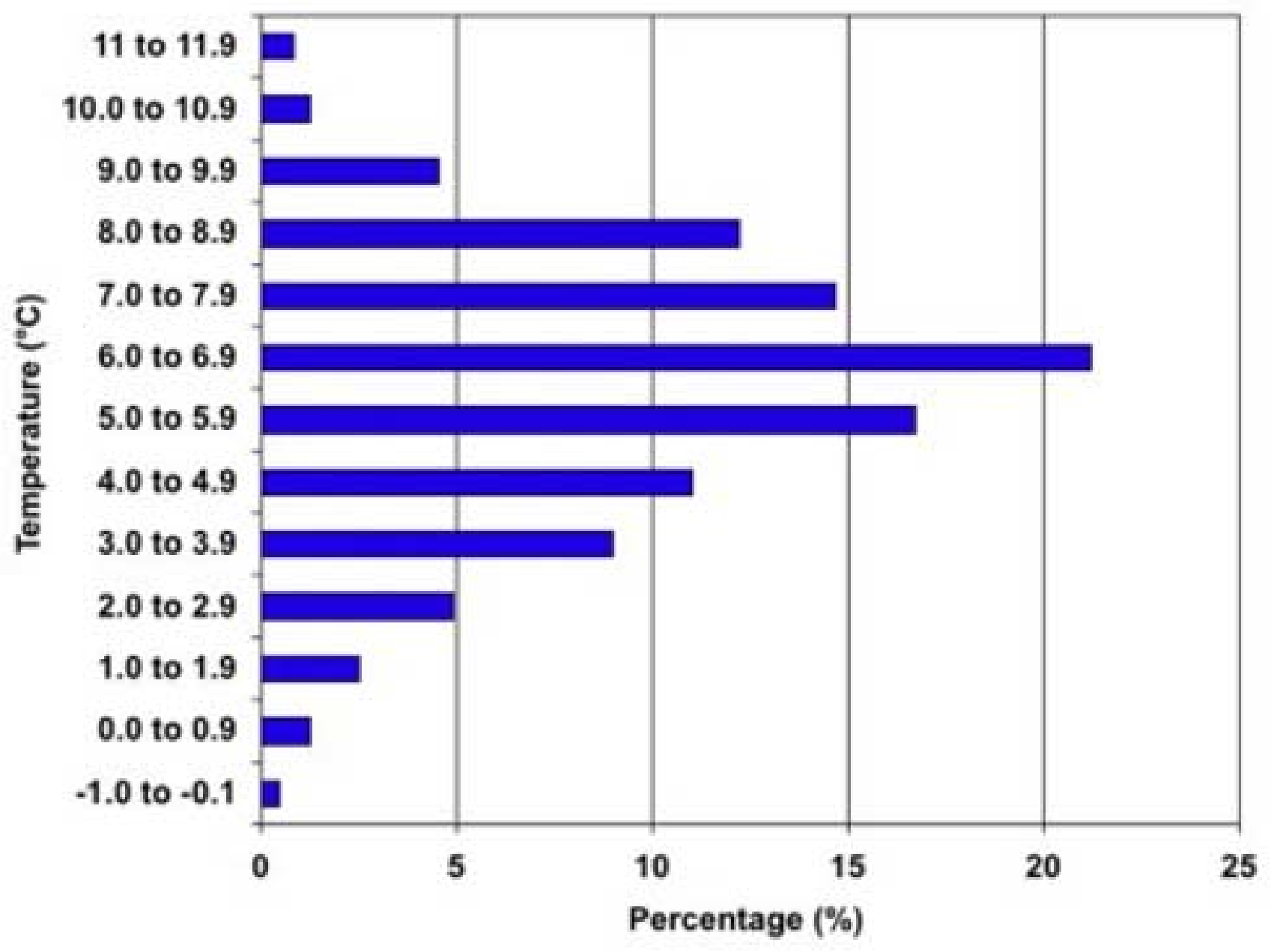




\begin{tabular}{|c|c|}
\hline Country & Reference \\
\hline US & Van Garde \& Woodburne, 1987 \\
\hline China & Shixiong \& Jing, 1990 \\
\hline UK & Rose etal., 1990 \\
\hline UK & $\begin{array}{l}\text { Evans et al., } 1991 \text { (published in Evans, 1992; James \& Evans, } \\
\text { 1992a; James \& Evans, 1992b) }\end{array}$ \\
\hline Northern Ireland & Flynn etal., 1992 \\
\hline France & Vic toria, 1993 (cited by Laguerre et al., 2002) \\
\hline The Netherlands & Lezenne Coulander, 1994 (cited by Notermans et al., 1997) \\
\hline New Zealand & O’Brien, 1997 \\
\hline Greece & Sergelid is et al., 1997 \\
\hline UK & Wors fold \& Griffith, 1997 \\
\hline USA & Daniels, 1998 \\
\hline UK & Johnson et al., 1998 \\
\hline Australia & Jay et al., 1999 \\
\hline US & Audits International, 1999 \\
\hline France & Laguerre et al., 2002 \\
\hline Northern Ireland & Jackson, 2003 \\
\hline US & Redmond \& Griffith, 2003 \\
\hline UK & Ghebrehewet \& Stevenson, 2003 \\
\hline New Zealand & ESR, 2004 (cited by Anon, 2007) \\
\hline Sweden & Mark linder et al., 2004 \\
\hline Ireland & Kennedy et al., 2005 \\
\hline Portugal & Azevedo et al., 2005 \\
\hline Greece & Koutsoumanis \& Taoukis, 2005, Taoukis et al., 2005 \\
\hline Netherlands & Terps tra et al., 2005 \\
\hline UK & Breen et al., 2006 \\
\hline
\end{tabular}




\begin{tabular}{|c|c|c|c|c|c|c|c|}
\hline Reference & Country & $\mathrm{n}=$ & Measurement & $\mathrm{T}_{\min }$ & $\mathrm{T}_{\text {mean }}$ & $\mathrm{T}_{\max }$ & $\%$ in temperature range \\
\hline Van Garde \& Woodburne, 1987 & US & - & Not known & & & & $21 \% \geq 10^{\circ} \mathrm{C}$ \\
\hline Rose et al., 1990 & UK & 75 & Not known & & $<5$ & 15 & $6 \%>5^{\circ} \mathrm{C}$ \\
\hline Evans et al., 1991 & UK & 252 & Data logger (3 levels: T, M, B) & 0.9 & 6.0 & 11.4 & $70 \%>5^{\circ} \mathrm{C}$ \\
\hline Flynn et al., 1992 & $\begin{array}{l}\text { Northern } \\
\text { Ireland }\end{array}$ & 150 & $\begin{array}{c}\text { Thermometer ( } 3 \text { levels: T, M, } \\
\text { B) }\end{array}$ & 0.8 & 6.5 & 12.6 & $71 \%>5^{\circ} \mathrm{C}$ \\
\hline Vic toria, $1993 *$ & France & 102 & $\begin{array}{c}\text { Thermometer (3 levels: T, M, } \\
\text { B) }\end{array}$ & & & 14 & $70 \%>6^{\circ} \mathrm{C}$ \\
\hline Lezenne Coulander, $1994 * *$ & Netherlands & 125 & Thermometer & & & & $30 \%<5^{\circ} \mathrm{C}, 42 \% 5$ to $7^{\circ} \mathrm{C}, 26 \% 7$ to $9^{\circ} \mathrm{C}, 2 \%>9^{\circ} \mathrm{C}$ \\
\hline O’Brien, 1997 & $\begin{array}{l}\text { New } \\
\text { Zealand }\end{array}$ & 50 & Thermometer (2 levels: T, B) & 0 & 4.9 & 11 & $60 \%>4^{\circ} \mathrm{C}$ \\
\hline Sergelid is et al., 1997 & Greece & 136 & Thermometer & & & & $50 \%>9{ }^{\circ} \mathrm{C}$ \\
\hline Worsfold \& Griffith 1997 & UK & 108 & Data logger (1 position) & 2 & 5.9 & 12 & $50 \%>5^{\circ} \mathrm{C}$ \\
\hline Daniels, 1998 & USA & 106 & Not known & & & & $69 \%>5^{\circ} \mathrm{C}$ \\
\hline Johnson et al., 1998 & UK & 645 & Thermometer & -2 & 7 & 13 & $70 \%>5^{\circ} \mathrm{C}$ \\
\hline Laguerre et al., 2002 & France & 119 & Data logger (3 levels: T, M, B) & 0.9 & 6.6 & 11.4 & $80 \%>5^{\circ} \mathrm{C}$ \\
\hline $\begin{array}{l}\text { Ghebrehewet \& S tevenson, } \\
2003\end{array}$ & UK & 901 & Not known & & & & $\begin{array}{l}69.3 \% 0 \text { to } 4^{\circ} \mathrm{C}, 27.9 \% 5 \text { to } 9^{\circ} \mathrm{C}, 2.8 \%>10^{\circ} \mathrm{C} \\
84.2 \%{ }^{\mathrm{a}} 0 \text { to } 4^{\circ} \mathrm{C}, 14.8 \%{ }^{\mathrm{a}} 5 \text { to } 9^{\circ} \mathrm{C}, 1.0 \%{ }^{\mathrm{a}}>10^{\circ} \mathrm{C}\end{array}$ \\
\hline ARS, $2004 * * *$ & $\begin{array}{l}\text { New } \\
\text { Zealand }\end{array}$ & 53 & Not known & & & & $33 \%>5^{\circ} \mathrm{C}$ \\
\hline Bakalis et al., 2004 & Greece & 110 & $\begin{array}{l}\text { Data logger (3 levels: T, M, B } \\
\text { and door) }\end{array}$ & & & & $\begin{array}{c}26 \%<4^{\circ} \mathrm{C}, 28 \% 4 \text { to } 6^{\circ} \mathrm{C}, 23 \% 6 \text { to } 8^{\circ} \mathrm{C}, 15 \% 8 \text { to } \\
10^{\circ} \mathrm{C}, 8 \% 10 \text { to } 12^{\circ} \mathrm{C}\end{array}$ \\
\hline Kennedy et al., 2005 & Ireland & 100 & Data logger (1 level M) & -7.9 & 5.4 & 20.7 & $59 \%>5^{\circ} \mathrm{C}$ \\
\hline Azevedo et al., 2005 & Portugal & 86 & Digital thermometer & & & & $70 \%>6^{\circ} \mathrm{C}$ \\
\hline Taoukis et al., 2005 & Greece & 250 & Data logger & -2 & 6.3 & & $50 \%>6^{\circ} \mathrm{C}, 10 \%>10^{\circ} \mathrm{C}$ \\
\hline Terpstra et al., 2005 & Netherlands & 31 & Glass thermometer & 3.8 & & 11.5 & $68 \%>7^{\circ} \mathrm{C}$ \\
\hline Breen et al., 2006 & UK & 24 & Glass thermometer in gel & & $\begin{array}{c}5.0 \\
\text { (mode) }\end{array}$ & & $33 \%>5^{\circ} \mathrm{C}$ \\
\hline
\end{tabular}

* cited by Laguerre et al. (2002), ${ }^{* *}$ cited by Notermans et al. (1997), ${ }^{* * *}$ Cited by Anon (2007), ${ }^{\text {a }} 2^{\text {nd }}$ visit 
Table 3

\begin{tabular}{ccc}
\hline \multirow{2}{*}{ Position } & \multicolumn{2}{c}{$\%$ of refrigerators } \\
\cline { 2 - 3 } & $\begin{array}{c}\text { Highest mean } \\
\text { temperature }\end{array}$ & $\begin{array}{c}\text { Lowest mean } \\
\text { temperature }\end{array}$ \\
\hline Top & 69.9 & 20.3 \\
Middle & 8.1 & 45.1 \\
Bottom & 22.0 & 34.6 \\
\hline
\end{tabular}




\begin{tabular}{cccccccc}
\hline & \multicolumn{2}{c}{ \% of lowest mean temperatures in: } & & \multicolumn{2}{c}{ \% of highest mean temperatures in: } \\
\cline { 2 - 3 } \cline { 6 - 8 } Refrige rator type & Top & Middle & Bottom & & Top & Middle & \multirow{2}{*}{ Bottom } \\
\hline Ice box & 48.1 & 41.6 & 10.4 & & 28.6 & 11.7 & 59.7 \\
Frid ge-freezer & 10.6 & 45.5 & 43.9 & & 84.6 & 8.9 & 6.5 \\
Larder & 0.0 & 50.0 & 50.0 & & 100.0 & 0.0 & 0.0 \\
\hline
\end{tabular}


Table 5

\begin{tabular}{cccc}
\hline Range in temperature $\left({ }^{\circ} \mathrm{C}\right)$ & Ice box & Fridge-freezer & Larder \\
Minimum temp range & 0.2 & 0.1 & 0.5 \\
Maximum temp range & 7.0 & 12.04 & 9.0 \\
Mean temp range & 1.8 & 3.4 & 3.7 \\
\hline
\end{tabular}




\begin{tabular}{cccc}
\hline Criterion & $\begin{array}{c}\text { Typicalcurrent } \\
\text { values }\end{array}$ & $\begin{array}{c}\text { Improved } \\
\text { specification }\end{array}$ & Achieved \\
\hline Variation of temperature with time & $\pm 5^{\circ} \mathrm{C}$ & $\pm 1^{\circ} \mathrm{C}$ & $\pm 0.3^{\circ} \mathrm{C}$ \\
Variation of temperature with pos ition & $\pm 5^{\circ} \mathrm{C}$ & $\pm 0.2^{\circ} \mathrm{C}$ \\
Cooling time for 3kg of warm food from $45^{\circ} \mathrm{C}$ & $720 \mathrm{~min}$ & $120 \mathrm{~min}$ & $45 \mathrm{~min}$ \\
$\begin{array}{c}\text { Temperature reco very of partially loaded } \\
\text { refrigerator after a 5 min door opening }\end{array}$ & $60 \mathrm{~min}$ & $30 \mathrm{~min}$ & $12 \mathrm{~min}$ \\
$\begin{array}{c}\text { Temperature reco very of partially loaded } \\
\text { refrigerator after a } 10 \text { min door opening }\end{array}$ & $180 \mathrm{~min}$ & $30 \mathrm{~min}$ & 12 \\
\hline
\end{tabular}

